\title{
Improved Efficiency of Miscible C02 Floods and Enhanced Prospects for C02 Flooding Heterogeneous Reservoirs
}

\author{
Quarterly Report \\ April 1 - June 30, 1998
}

\section{By \\ Reid B. Grigg; David S. Schechter; Shih-Hsien (Eric) Chang Boyun (Gordon) Guo; Jyun-Syung Tsau}

Work Performed Under Contract No.: DE-FG26-97BC15747

\author{
For \\ U.S. Department of Energy \\ Office of Fossil Energy \\ Federal Energy Technology Center \\ P.O. Box 880 \\ Morgantown, West Virginia 26507-0880
}

By

New Mexico Petroleum Recovery Research Center

New Mexico Institute of Mining and Technology

Socorro, New Mexico 87801 


\section{Disclaimer}

This report was prepared as an account of work sponsored by an agency of the United States Government. Neither the United States Government nor any agency thereof, nor any of their employees, makes any warranty, express or implied, or assumes any legal liability or responsibility for the accuracy, completeness, or usefulness of any information, apparatus, product, or process disclosed, or represents that its use would not infringe privately owned rights. Reference herein to any specific commercial product, process, or service by trade

name, trademark, manufacturer, or otherwise does not necessarily constitute or imply its endorsement, recommendation, or favoring by the United States Government or any agency thereof. The views and opinions of authors expressed herein do not necessarily state or reflect those of the United States Government or any agency thereof. 
Quarterly Technical Progress Report

IMPROVED EFFICIENCY OF MISCIBLE $\mathrm{CO}_{2}$ FLOODS AND ENHANCED PROSPECTS FOR $\mathrm{CO}_{2}$ FLOODING HETEROGENEOUS RESERVOIRS

DOE Contract No. DE-FG26-97BC15047--05

New Mexico Petroleum Recovery Research Center

New Mexico Institute of Mining and Technology

Socorro, NM 87801

(505) 835-5142

Report Date:

Contract Date:

Completion Date:

DOE Award of $1^{\text {st }}$ year:

Program Manager:

Principal Investigators:

Contracting Officer's Representative:

Reporting Period:
July 7, 1998

June 1, 1997

May 31, 2000

$\$ 319,548$

Reid B. Grigg

Reid B. Grigg

David S. Schechter

Jerry F. Casteel

April 1, 1998-June 30, 1998 


\section{DISCLAIMER}

This report was prepared as an account of work sponsored by an agency of the United States Government. Neither the United States Government nor any agency thereof, nor any of their employees, makes any warranty, express or implied, or assumes any legal liability or responsibility for the accuracy, completeness, or usefulness of any information, apparatus, product, or process disclosed, or represents that its use would not infringe privately owned rights. Reference herein to any specific commercial product, process, or service by trade name, trademark, manufacturer, or otherwise does not necessarily constitute or imply its endorsement, recommendation, or favoring by the United States Government or any agency thereof. The views and opinions of authors expressed herein do not necessarily state or reflect those of the United States Government or any agency thereof.
Abstract
In this quarter, we used parallel isolated composite core to test the effectiveness of foam on oil recovery efficiency. This composite core differs from the previous core in two areas: 1) Pyrex® glass beads were used in the center region to form a high permeability region and 2) a fired Berea sandstone was used in the annulus region to form a low permeability region. We also started to conduct surfactant adsorption measurements on coreflooding substrates. Static measurements with three anionic surfactants were conducted on Pyrex ${ }^{\circledR}$ glass beads. Surfactant concentrations were determined to calculate the amount of surfactant adsorbed on the substrate. The preliminary results showed that the loss of surfactant due to adsorption at $500 \mathrm{ppm}$ concentration were $0.34 \mathrm{mg} / \mathrm{cm}^{3}, 0.29 \mathrm{mg} / \mathrm{cm}^{3}$, and $0.19 \mathrm{mg} / \mathrm{cm}^{3}$ for surfactants Alipa®CD128, Chaser ${ }^{\mathrm{TM}} \mathrm{CD} 1040$ and Dowfax ${ }^{\mathrm{TM}} 8390$, respectively.
Simulations were performed to assess the applicability of horizontal wells as a tool to increase oil recovery in $\mathrm{CO}_{2}$ injection projects. To date, tests show that:
1) an injector with a shorter horizontal well length results in higher oil recovery;
2) a producer with a longer well length results in higher oil recovery;
3) the length of the producer has more effect on recovery than the length of the injector;
4) the use of a vertical injector results in higher oil recovery; and
5) the use of horizontal producer results in higher oil recovery. 


\section{Executive Summary}

A grant, "Improved Efficiency of Miscible $\mathrm{CO}_{2}$ Floods and Enhanced Prospects for $\mathrm{CO}_{2}$ Flooding Heterogeneous Reservoirs," DOE Contract No. DE-FG26-97BC15047, was awarded and started on June 1, 1997. This project examines three major areas in which $\mathrm{CO}_{2}$ flooding can be improved: fluid and matrix interactions, conformance control/sweep efficiency, and reservoir simulation for improved oil recovery.

We started conducting surfactant adsorption measurements on surfactants that were used in our foam flowing experiments. Static measurements were conducted on Pyrex ${ }^{\circledR}$ glass beads with three anionic surfactants. The preliminary results showed that the loss of surfactant due to adsorption at $500 \mathrm{ppm}$ concentration were $0.34 \mathrm{mg} / \mathrm{cm}^{3}, 0.29 \mathrm{mg} / \mathrm{cm}^{3}$, and $0.19 \mathrm{mg} / \mathrm{cm}^{3}$ for surfactants Alipa ${ }^{\circledR C D} 128$, Chaser ${ }^{\mathrm{TM}} \mathrm{CD} 1040$ and Dowfax ${ }^{\mathrm{TM}} 8390$, respectively. Continuous static measurements will be performed on other surfactants, while dynamic measurements are planned on all the surfactant samples with Berea sandstone and carbonate core samples. We will also be examining sacrificial agents to satisfy substrate adsorption.

To successfully apply horizontal wells, reliable and accurate tools are needed for their design. The primary motivation of our study was to assess the technical feasibility of applying $\mathrm{CO}_{2}$ flooding using horizontal wells. A pseudomiscible reservoir simulator, MASTER, which has been modified to incorporate a horizontal wellbore model, has been used to make comparisons of $\mathrm{CO}_{2}$ flooding performance with several combinations of horizontal and vertical wells and various alternative reservoir descriptions. The results this quarter indicate that:

1) an injector with a shorter horizontal well length results in higher oil recovery;

2) a producer with a longer well length results in higher oil recovery;

3) the length of the producer has more effect on recovery than the length of the injector;

4) the use of a vertical injector results in higher oil recovery; and

5) the use of horizontal producer results in higher oil recovery. 


\section{Introduction}

Because of the importance of $\mathrm{CO}_{2}$ flooding to future oil recovery in New Mexico, west Texas, and the United States, the Petroleum Recovery Research Center (PRRC) pursues a vigorous research program to improve the effectiveness of $\mathrm{CO}_{2}$ flooding in heterogeneous reservoirs. The results of our research continue to expand the list of viable candidates for $\mathrm{CO}_{2}$ flooding. Our primary interests are to include more low-pressure reservoirs and many more heterogeneous or fractured reservoirs in our research.

Continued support for oil recovery research by $\mathrm{CO}_{2}$ flooding has been provided by the U.S. Department of Energy for an additional three years through a grant entitled: "Improved Efficiency of Miscible $\mathrm{CO}_{2}$ Floods and Enhanced Prospects for $\mathrm{CO}_{2}$ Flooding Heterogeneous Reservoirs." The New Mexico Petroleum Recovery Research Center (PRRC) is well known as a premier institution for improved oil recovery (IOR) research and, in particular, for its research on the use of high-pressure $\mathrm{CO}_{2}$ injection. The extension will continue the progress on understanding $\mathrm{CO}_{2}$ flooding in heterogeneous reservoirs, further the development of methods to enable $\mathrm{CO}_{2}$ flooding in more heterogeneous reservoirs, and continue the dissemination of this information to promote successful implementation of these methods. The research will proceed in three related areas:

- Fluid and matrix interactions (understanding the problems): interfacial tension (IFT), phase behavior, development of miscibility, capillary number $(\mathrm{Nc})$, injectivity, wettability, gravity drainage, etc.

- Conformance control/sweep efficiency (solving the problems): reduction of mobility using foam, diversion by selective mobility reduction (SMR) using foam, improved injectivity, WAG, horizontal wells, etc.

- Reservoir simulation for improved oil recovery (predicting results): gravity drainage, SMR, $\mathrm{CO}_{2}$ /foam flooding, IFT, injectivity profile, horizontal wells, and naturally fractured reservoirs.

All areas originate from research on the mechanics of oil recovery by high-pressure $\mathrm{CO}_{2}$. Experience gained during the current project is relevant to our continued efforts. Future research in each of the three areas will increase both the quantity of oil produced and the efficiency of oil 
recovery from $\mathrm{CO}_{2}$ flooding. Special attention will be given to disseminating research results through an extensive technology transfer effort. Because of the importance of $\mathrm{CO}_{2}$ flooding in New Mexico reservoirs, additional funds are being provided through a combination of state and industrial funds.

The "Quarterly Technical Progress Report" summarizes this quarter's activities in three areas: 1) effectiveness of foam on oil recovery in different core configurations; 2) measurements of surfactant adsorption on surfactants on various substrates; and 3) our efforts to assess the technical feasibility of applying $\mathrm{CO}_{2}$ flooding through a modeling study using horizontal wells; with an extended report on the third activity.

\section{Summary}

In this quarter, we continued core flooding tests on foam experiments. A parallel isolated composite core was used to test effectiveness of foam on oil recovery efficiency in a different core configuration. This composite core differs from the previous core in two areas: 1) Pyrex ${ }^{\circledR}$ glass beads were used in the center region to form a high permeability region with permeability of $5960 \mathrm{md}$, and 2) a fired Berea sandstone was used in the annulus region to form a low permeability region with permeability of $79 \mathrm{md}$. Tests are in progress and the complete results will be included in the next quarterly report.

We also started to conduct surfactant adsorption measurements on surfactants that were used in our foam flowing experiments. Static measurements were conducted with three anionic surfactants on Pyrex ${ }^{\circledR}$ glass beads. A refractometer was used to analyze surfactant concentration and determine the amount of surfactant adsorbed on the substrate. The preliminary results showed that the loss of surfactant at $500 \mathrm{ppm}$ concentration due to adsorption were $0.34 \mathrm{mg} / \mathrm{cm}^{3}$, $0.29 \mathrm{mg} / \mathrm{cm}^{3}$, and $0.19 \mathrm{mg} / \mathrm{cm}^{3}$ for surfactants Alipa ${ }^{\circledR}$ CD128, Chaser ${ }^{\mathrm{TM}} \mathrm{CD} 1040$ and Dowfax $^{\text {TM} 8390, ~ r e s p e c t i v e l y . ~ C o n t i n u o u s ~ s t a t i c ~ m e a s u r e m e n t s ~ w i l l ~ b e ~ p e r f o r m e d ~ o n ~ o t h e r ~}$ surfactants while dynamic measurements are planned on all the surfactant samples with Berea sandstone and carbonate core samples.

To successfully apply horizontal wells, reliable and accurate tools are needed for their design. This quarter we ran a number of simulations and found that :

1) an injector with a shorter horizontal well length results in higher oil recovery;

2) a producer with a longer well length results in higher oil recovery; 
3) the length of the producer has more effect on recovery than the length of the injector;

4) the use of a vertical injector results in higher oil recovery; and

5) the use of horizontal producer results in higher oil recovery.

\section{Horizontal Wells}

Important technological advances during the last decade have made it possible to drill and complete horizontal wells economically. Horizontal wells provide the opportunity for substantial increases in productivity and sweep per well in any oil displacement processes. Horizontal wells can also be placed selectively at a particular horizon, so that they will be adjacent to the most abundant oil zone. In addition to their application as producers, horizontal wells can be used as injectors. Because of the better sweep efficiencies and higher injectivities possible with horizontal wells, all improved oil recovery (IOR) methods would seem to benefit by their use. ${ }^{1}$ To successfully apply horizontal wells, reliable and accurate tools are needed for their design. A reservoir simulator with horizontal well capabilities can provide guidance in the design of well lengths, locations, and other factors associated with horizontal wells.

The primary motivation of our study was to assess the technical feasibility of applying $\mathrm{CO}_{2}$ flooding using horizontal wells. A pseudomiscible reservoir simulator, MASTER, which has been modified to incorporate a horizontal wellbore model developed by Babu et al., ${ }^{2}$ has been used to make comparisons of $\mathrm{CO}_{2}$ flooding performance with several combinations of horizontal and vertical wells and various alternative reservoir descriptions. The equivalent wellblock radius formulation of Babu et al. is general and is valid for both vertical and horizontal wells, for any well locations and for any anisotropy. MASTER, which was modified by incorporating a newly developed foam model, was previously used to investigate foam flooding

processes. ${ }^{\mathbf{3 , 4}}$ One of the objectives of this study was to conduct a systematic investigation of $\mathrm{CO}_{2}$ flooding using horizontal wells in conjunction with foam. MASTER, which was supplied by the U.S. Department of Energy, is an extension of the so-called black-oil model and uses the mixing-rule approach to calculate the effective fluid density and viscosity. Readers are referred to the original report of Ammer et al. ${ }^{\mathbf{5}}$ for the detailed descriptions of MASTER. 


\section{Problem Statement}

The problem deals with oil recovery in a thin reservoir. The reservoir is represented by a 9x9x6 grid system. Two hypothetical reservoir descriptions were used. In the first reservoir description, the reservoir description given in the Seventh SPE Comparative Solution Project (SPE 21221) ${ }^{6}$ was used. The grid dimensions in the $\mathrm{x}$-direction are $300 \mathrm{ft}$ for all grids. The grid dimensions in the y-direction are 620,400, 200,100,60,100, 200, 400, and $620 \mathrm{ft}$, respectively. The grid dimensions in the vertical direction (z-direction) from layer 1 to layer 6 are 20, 20, 20, 20, 30, and $50 \mathrm{ft}$, respectively. Simulations were made using this reservoir description with a pair of vertical wells, a pair of horizontal wells, and a combination of horizontal and vertical wells. For the cases with horizontal wells, the injector was placed at the center of layer $6(\mathrm{~J}=5, \mathrm{~K}=6)$ parallel to the $\mathrm{x}$-direction and the producer was placed at the center of layer $1(\mathrm{~J}=5, \mathrm{~K}=1)$ parallel to the $\mathrm{x}$-direction. For the cases with vertical wells, the injector was placed along one side of the reservoir $(I=1, J=5)$ and the producer was placed along the opposite side $(I=9, J=5)$. Note that $I$, $\mathrm{J}$, and $\mathrm{K}$ are the grid indices in the $\mathrm{x}-, \mathrm{y}-$, and $\mathrm{z}$-directions, respectively. The wellbore has an inside radius of $0.1875 \mathrm{ft}$.

The second reservoir description differs from the first reservoir description in the grid dimensions in the y-direction and in the well locations. The grid dimensions in the y-direction are 60, 100, 260, 600, 660, 600, 260, 100, and $60 \mathrm{ft}$, respectively. For the cases with horizontal wells, the injector was placed at one side of the reservoir in layer $6(\mathrm{~J}=1, \mathrm{~K}=6)$ parallel to the $\mathrm{X}$ direction and the producer was placed at the opposite side of the reservoir in layer $1(\mathrm{~J}=9, \mathrm{~K}=1)$ parallel to the $\mathrm{x}$-direction. For the cases with vertical wells, the injector was placed at one corner of the reservoir $(I=1, J=1)$ and the producer was placed at the opposite corner $(I=9, J=9)$.

Black-oil fluid property, relative permeability, reservoir and capillary pressure data from SPE 21221 are used. $^{6}$ Table 1 shows the reservoir data and initial conditions. The initial bubblepoint pressure is equal to the initial grid oil pressure in each grid. Fluid property data are given in Table 2. Relative permeabilities and capillary pressures for oil-water and oil-gas systems are reported in Tables 3 and 4. Table 5 lists the $\mathrm{CO}_{2}$ fluid property data.

Three different kind of injection schemes were used in simulations including (1) pure water, (2) pure $\mathrm{CO}_{2}$, and (3) water alternating $\mathrm{CO}_{2}$ (WAG) injection. The injection periods for the pure water and $\mathrm{CO}_{2}$ injection are 1500 days. The injection scheme for the WAG injection is 300 days of water injection followed by two cycles of WAG injection, with each cycle consisting 
of 300 days of water injection and 300 days of $\mathrm{CO}_{2}$ injection. Simulations were made using the above two reservoir descriptions with a pair of vertical wells, a pair of horizontal wells, and a combination of horizontal and vertical wells. Six of these simulations are described in Table 6, cases $1-6$.

\section{Results and Discussion}

Cases 2 and 3 were designed to examine the effect of injector well length on the recovery. In case 2, the injector is $1200 \mathrm{ft}$ long and in case 3 it is $2700 \mathrm{ft}$ long. Simulation results of oil rate and cumulative oil production using the first reservoir description are plotted Figs. 1 and 2 for the WAG injection scheme. The cumulative oil production is clearly higher for case 2 with a well length of $1200 \mathrm{ft}$. However, this effect is not very significant for simulations using the second reservoir description, as shown in Fig. 3. Similar results were obtained for the pure $\mathrm{CO}_{2}$ and water injection schemes.

Cases 3 and 4 were designed to examine the effect of well length of the producer on the recovery. In case 3 the producer is $900 \mathrm{ft}$ long and in case 4, it is $2100 \mathrm{ft}$ long. Simulation results of oil rate and cumulative oil production using the first reservoir description are plotted in Figs. 4 and 5 for the WAG injection scheme. The cumulative oil production is clearly higher in case 4, with a well length of $2100 \mathrm{ft}$. The same effect on the recovery was also obtained using the second reservoir description (see Fig. 6). This indicates that the length of the producer has more effect on recovery than the length of the injector. Similar results were obtained for the pure $\mathrm{CO}_{2}$ and water injection schemes.

Cases 1 and 2 were designed to examine the effect of a horizontal injector, as compared to a vertical injector, on recovery. In case 1 , the injector is a vertical well while it is a horizontal well in case 2. The producers for both cases are horizontal wells. Simulation results of cumulative oil production using the first reservoir description are plotted in Fig. 7 for the WAG injection scheme. The cumulative oil production is clearly higher in case 1, with a vertical injector. However, there is no effect for simulations using the second reservoir description. Similar results were obtained for the water injection schemes. There is no effect for simulations with pure $\mathrm{CO}_{2}$ injection.

Cases 5 and 6 were also designed to examine the effect of a horizontal injector, as compared to a vertical injector, on recovery. In case 5, the injector is a vertical well while it is a 
horizontal well in case 6. The producers for both cases are vertical wells. Simulation results of cumulative oil production using the first reservoir description are plotted in Fig. 8 for the WAG injection scheme. The cumulative oil production is clearly higher in case 5, with a vertical injector. However, there is no effect for simulations using the second reservoir description. Similar results were obtained for the water injection schemes. There is no effect for simulations with pure $\mathrm{CO}_{2}$ injection.

Cases 2 and 6 were designed to examine the effect of a horizontal producer, as compared to a vertical producer, on recovery. In case 6 , the producer is a vertical well while it is a horizontal well in case 2. The injectors for both cases are horizontal wells. Simulation results of cumulative oil production using the first reservoir description are plotted in Fig. 9 for the WAG injection scheme. The cumulative oil production is clearly higher for case 2 , with a horizontal producer. The same effect on recovery was also obtained using the second reservoir description. Similar results were obtained for the pure $\mathrm{CO}_{2}$ and water injection schemes.

Cases 1 and 5 were designed to examine the effect of a horizontal producer, as compared to a vertical producer, on recovery. In case 5, the producer is a vertical well while it is a

horizontal well in case 1 . The injectors for both cases are vertical wells. Simulation results of cumulative oil production using the first reservoir description are plotted Fig. 10 for the WAG injection scheme. The cumulative oil production is clearly higher for case 1, with a horizontal producer. The same effect on recovery was also obtained using the second reservoir description. Similar results were obtained for the pure $\mathrm{CO}_{2}$ and water injection schemes.

\section{Conclusions}

1. The injector with a shorter well length resulted in higher oil recovery.

2. The producer with a longer well length resulted in higher oil recovery.

3. The length of the producer has more effect on recovery than the length of the injector.

4. The use of a vertical injector resulted in higher oil recovery.

5. The use of a horizontal producer resulted in higher oil recovery. 


\section{References}

1. Taber, J.J. and Seright, R.S.: "Horizontal Injection and Production Wells for EOR or Waterflooding," paper SPE 23952 presented at the 1992 SPE Permian Basin Oil and Gas Recovery Conference, Midland, TX, March 18-20.

2. Babu, D.K. et al.: "The Relation Between Wellblock and Wellbore Pressures in Numerical Simulation of Horizontal Wells," SPERE (August 1991), 324-328.

3. Chang, S.-H. and Grigg, R.B.: "Foam Displacement Modeling in $\mathrm{CO}_{2}$ Flooding Processes," paper SPE/DOE 35401 presented at the 1996 SPE/DOE Symposium on Improved Oil Recovery, Tulsa, April 21-24.

4. Chang, S.-H. and Grigg, R.B.: "History Matching and Modeling the $\mathrm{CO}_{2}$-Foam Pilot Test at EVGSAU,' paper SPE 39793 presented at the 1998 SPE Permian Basin Oil and Gas Recovery Conference, Midland, March 25-27.

5. Ammer, R.J. et al.: "Miscible Applied Simulation Techniques for Energy Recovery-Version 2.0," Report to U.S. Department of Energy, Contract No. DOE/BC-91/2/SP (February 1991).

6. Nghiem, L, Collins, D.A., and Sharma, R.: "Seventh SPE Comparative Solution Project: Modeling of Horizontal Wells in Reservoir Simulation," paper SPE 21221 presented at the 1991 Symposium on Reservoir Simulation, Anaheim, Feb. 17-20. 
Table 1. Reservoir Data and Initial Conditions

\begin{tabular}{|ccccccc|}
\hline Layer & $\begin{array}{c}\text { Thickness } \\
(\mathrm{ft})\end{array}$ & $\begin{array}{c}\text { Depth* } \\
(\mathrm{ft})\end{array}$ & Porosity & $\begin{array}{c}\text { Oil } \\
\text { Pressure } \\
(\mathrm{psia})\end{array}$ & $\begin{array}{c}\text { Oil } \\
\text { Saturation }\end{array}$ & $\begin{array}{c}\text { Water } \\
\text { Saturation }\end{array}$ \\
\hline 1 & 20 & 3600 & 0.2 & 3600 & 0.711 & 0.289 \\
2 & 20 & 3620 & 0.2 & 3608 & 0.652 & 0.348 \\
3 & 20 & 3640 & 0.2 & 3616 & 0.527 & 0.473 \\
4 & 20 & 3660 & 0.2 & 3623 & 0.351 & 0.649 \\
5 & 30 & 3685 & 0.2 & 3633 & 0.131 & 0.869 \\
6 & 50 & 3725 & 0.2 & 3650 & 0.000 & 1.000 \\
\hline
\end{tabular}

* Depth to center of layer

Table 2. Fluid Property Data (assuming water viscosity to be $0.96 \mathrm{cp}$ and the gas-water ratio zero at all pressures).

\begin{tabular}{|ccccccc|}
\hline & & Oil & Solution & Water & & Gas \\
& Formation & Gas & Formation & & Formation \\
Volume & Gas & Volume \\
Pressure & Viscosity & Factor & Ratio & Factor & Viscosity & Factor \\
$(\mathrm{psia})$ & $(\mathrm{cp})$ & $(\mathrm{RB} / \mathrm{STB})$ & $(\mathrm{SCF} / \mathrm{STB})$ & $(\mathrm{RB} / \mathrm{STB})$ & $(\mathrm{cp})$ & $(\mathrm{RB} / \mathrm{SCF})$ \\
\hline 400 & 1.17 & 1.0120 & 165 & 1.0130277 & 0.0130 & 0.00590 \\
800 & 1.14 & 1.0255 & 335 & 1.0118106 & 0.0135 & 0.00295 \\
1200 & 1.11 & 1.0380 & 500 & 1.0105936 & 0.0140 & 0.00196 \\
1600 & 1.08 & 1.0510 & 665 & 1.0093766 & 0.0145 & 0.00147 \\
2000 & 1.06 & 1.0630 & 828 & 1.0081595 & 0.0150 & 0.00118 \\
2400 & 1.03 & 1.0750 & 985 & 1.0069425 & 0.0155 & 0.00098 \\
2800 & 1.00 & 1.0870 & 1130 & 1.0057254 & 0.0160 & 0.00084 \\
3200 & 0.98 & 1.0985 & 1270 & 1.0045084 & 0.0165 & 0.00074 \\
3600 & 0.95 & 1.1100 & 1390 & 1.0032914 & 0.0170 & 0.00065 \\
4000 & 0.94 & 1.1200 & 1500 & 1.0020743 & 0.0175 & 0.00059 \\
4400 & 0.92 & 1.1300 & 1600 & 1.0008573 & 0.0180 & 0.00054 \\
4800 & 0.91 & 1.1400 & 1676 & 0.9996402 & 0.0185 & 0.00049 \\
5200 & 0.90 & 1.1480 & 1750 & 0.9984232 & 0.0190 & 0.00045 \\
5600 & 0.89 & 1.1550 & 1810 & 0.9972062 & 0.0195 & 0.00042 \\
\hline
\end{tabular}


Table 3. Oil-Water Relative Permeabilities and Capillary Pressure

\begin{tabular}{|cccc|}
\hline $\begin{array}{c}\text { Water } \\
\text { Saturation }\end{array}$ & $\begin{array}{c}\text { Oil } \\
\text { Rel. Perm. }\end{array}$ & $\begin{array}{c}\text { Water } \\
\text { Rel. Perm }\end{array}$ & $\begin{array}{c}\text { Capillary } \\
\text { Pressure } \\
\text { (psia) }\end{array}$ \\
\hline 0.22 & 1.0000 & 0.00 & 6.30 \\
0.30 & 0.4000 & 0.07 & 3.60 \\
0.40 & 0.1250 & 0.15 & 2.70 \\
0.50 & 0.0649 & 0.24 & 2.25 \\
0.60 & 0.0048 & 0.33 & 1.80 \\
0.80 & 0.0000 & 0.65 & 0.90 \\
0.90 & 0.0000 & 0.83 & 0.45 \\
1.00 & 0.0000 & 1.00 & 0.00 \\
\hline
\end{tabular}

Table 4. Oil-Gas Relative Permeabilities and Capillary Pressure

\begin{tabular}{|cccc|}
\hline $\begin{array}{c}\text { Gas } \\
\text { Saturation }\end{array}$ & $\begin{array}{c}\text { Oil } \\
\text { Rel. Perm. }\end{array}$ & $\begin{array}{c}\text { Gas } \\
\text { Rel. Perm }\end{array}$ & $\begin{array}{c}\text { Capillary } \\
\text { Pressure } \\
\text { (psia) }\end{array}$ \\
\hline 0.00 & 1.00 & 0.0000 & 0.0 \\
0.04 & 0.60 & 0.0000 & 0.2 \\
0.10 & 0.33 & 0.0220 & 0.5 \\
0.20 & 0.10 & 0.1000 & 1.0 \\
0.30 & 0.02 & 0.2400 & 1.5 \\
0.40 & 0.00 & 0.3400 & 2.0 \\
0.50 & 0.00 & 0.4200 & 2.5 \\
0.60 & 0.00 & 0.5000 & 3.0 \\
0.70 & 0.00 & 0.8125 & 3.5 \\
0.78 & 0.00 & 1.0000 & 3.9 \\
\hline
\end{tabular}


Table 5. $\mathrm{CO}_{2}$ Property Data (assuming $\mathrm{CO}_{2}$ solubility in water to be zero and the water formation volume factor one for all pressures)

\begin{tabular}{|c|c|c|c|c|c|c|}
\hline $\begin{array}{c}\text { Pressure } \\
\text { (psia) }\end{array}$ & $\begin{array}{c}\mathrm{CO}_{2} \\
\text { Viscosity } \\
\text { (cp) }\end{array}$ & $\begin{array}{c}\mathrm{CO}_{2} \\
\text { Formation } \\
\text { Volume } \\
\text { Factor } \\
\text { (RB/STB) }\end{array}$ & $\begin{array}{c}\mathrm{CO}_{2} \\
\text { Solubility } \\
\text { in } \\
\text { Oil } \\
\text { (SCF/STB) }\end{array}$ & $\begin{array}{c}\text { Oil } \\
\text { Formation } \\
\text { Volume } \\
\text { Factor } \\
\text { (RB/STB) }\end{array}$ & $\begin{array}{c}\text { Oil } \\
\text { Viscosity } \\
\text { (cp) }\end{array}$ & $\begin{array}{c}\text { Water } \\
\text { Viscosity } \\
\text { (cp) }\end{array}$ \\
\hline 500 & 0.012 & 0.031450 & 117.6 & 1.1017 & 0.995 & 0.96 \\
\hline 1000 & 0.013 & 0.014210 & 222.6 & 1.1478 & 0.974 & 0.96 \\
\hline 1200 & 0.014 & 0.011430 & 267.7 & 1.1677 & 0.964 & 0.96 \\
\hline 1500 & 0.016 & 0.008750 & 341.4 & 1.1997 & 0.949 & 0.96 \\
\hline 1800 & 0.018 & 0.007110 & 421.5 & 1.2350 & 0.934 & 0.96 \\
\hline 2000 & 0.019 & 0.006340 & 479.0 & 1.2600 & 0.924 & 0.96 \\
\hline 2500 & 0.023 & 0.005100 & 634.1 & 1.3278 & 0.900 & 0.96 \\
\hline 3000 & 0.027 & 0.004380 & 789.3 & 1.3956 & 0.887 & 0.96 \\
\hline 3500 & 0.031 & 0.003930 & 944.4 & 1.4634 & 0.875 & 0.96 \\
\hline 4000 & 0.034 & 0.003610 & 1099.5 & 1.5312 & 0.867 & 0.96 \\
\hline 4500 & 0.037 & 0.003380 & 1254.7 & 1.5991 & 0.859 & 0.96 \\
\hline 4800 & 0.038 & 0.003270 & 1347.8 & 1.6398 & 0.855 & 0.96 \\
\hline 5600 & 0.039 & 0.003200 & 1550.0 & 1.7000 & 0.850 & 0.96 \\
\hline
\end{tabular}

Table 6. Summary for injector and producer well types and conditions. Maximum bottomhole pressure for all injectors was 3700 psia, with injection rate of 6000 STB/D for water and 6000 MCF/D for gas. Minimum bottomhole pressure for all producers was 1500 psia.

\begin{tabular}{|c|c|c|c|c|c|c|}
\hline & \multicolumn{3}{|c|}{ Injector } & \multicolumn{3}{c|}{ Producer } \\
\hline Case & Type & $\begin{array}{c}\text { Horizontal } \\
\text { distance, } \boldsymbol{f t}\end{array}$ & Grid indices & Type & $\begin{array}{c}\text { Horizontal } \\
\text { distance, } \boldsymbol{f t}\end{array}$ & Grid indices \\
\hline 1 & Vertical (V) & --- & $\mathrm{K}=4,6$ & $\mathrm{H}$ & 900 & $\mathrm{I}=6,8$ \\
\hline 2 & Horizontal (H) & 1200 & $\mathrm{I}=1,4$ & $\mathrm{H}$ & 900 & $\mathrm{I}=6,8$ \\
\hline 3 & $\mathrm{H}$ & 2700 & $\mathrm{I}=1,9$ & $\mathrm{H}$ & 900 & $\mathrm{I}=6,8$ \\
\hline 4 & $\mathrm{H}$ & 2700 & $\mathrm{I}=1,9$ & $\mathrm{H}$ & 2100 & $\mathrm{I}=2,8$ \\
\hline 5 & $\mathrm{~V}$ & --- & $\mathrm{K}=4,6$ & $\mathrm{~V}$ & --- & $\mathrm{K}=1,3$ \\
\hline 6 & $\mathrm{H}$ & 1200 & $\mathrm{~K}=1,4$ & $\mathrm{~V}$ & --- & $\mathrm{K}=1,3$ \\
\hline
\end{tabular}


OIL PRODUCTION RATE

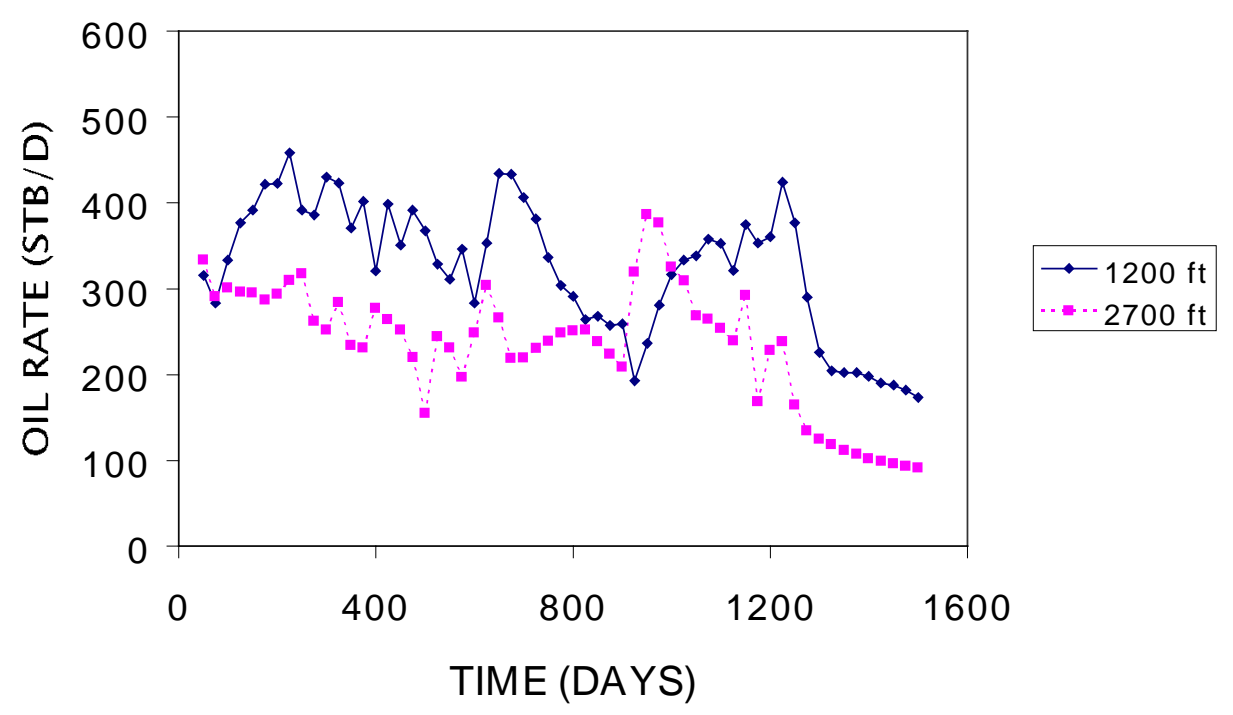

Fig. 1. Sensitivity of oil rate to well length of the injector.

\section{CUMULATIVE OIL PRODUCTION}

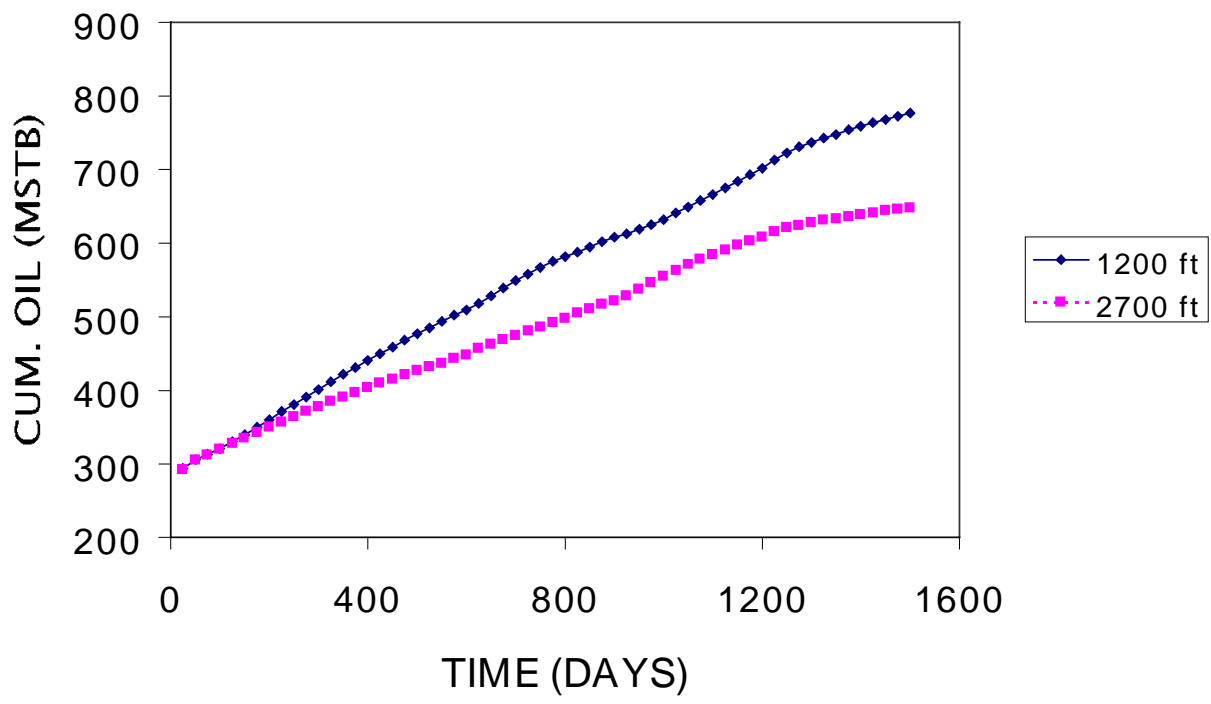

Fig. 2. Sensitivity of cumulative oil production to well length of the injector. 
CUMULATIVE OIL PRODUCTION

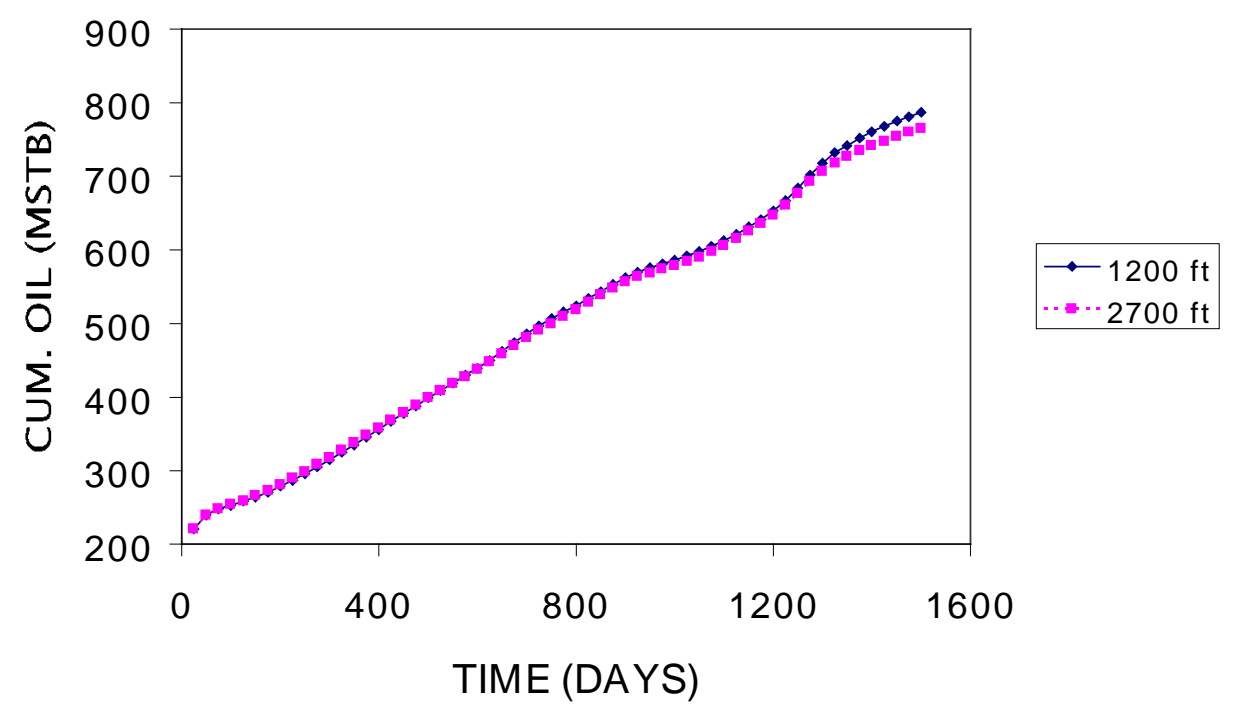

Fig. 3. Sensitivity of cumulative oil production to well length of the injector (with the second reservoir description).

OIL PRODUCTION RATE

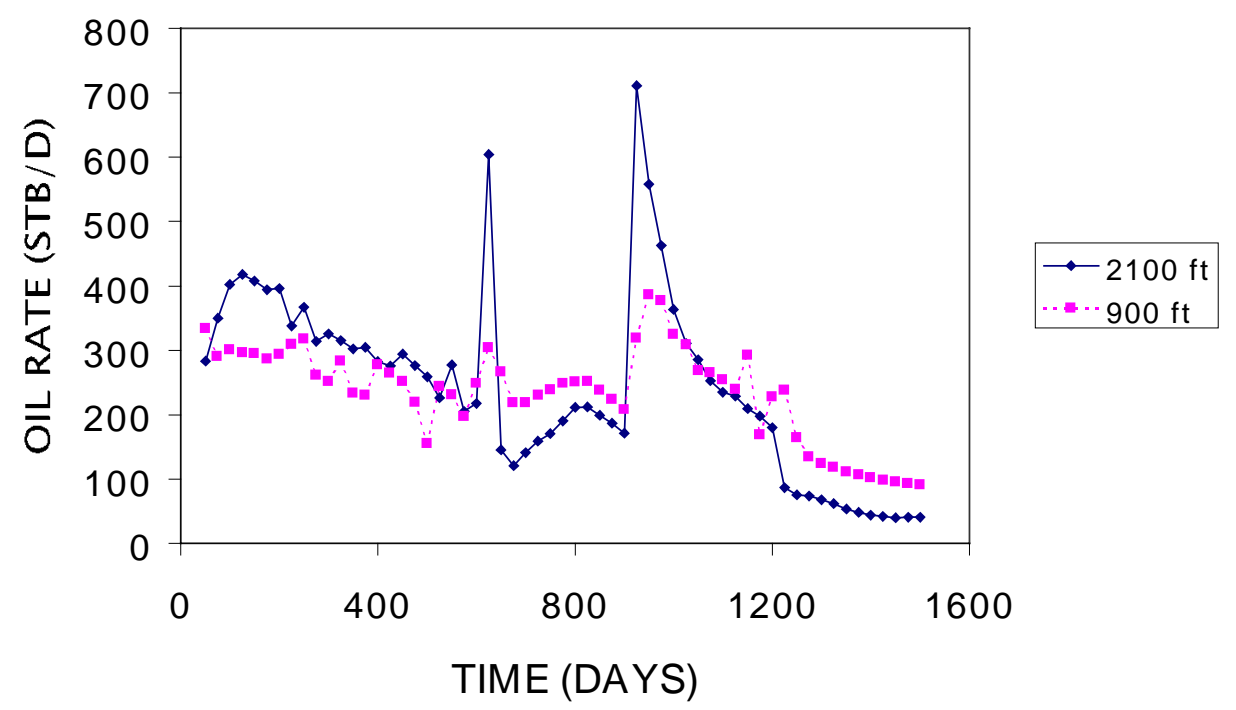

Fig. 4. Sensitivity of oil rate to well length of the producer. 
CUMULATIVE OIL PRODUCTION

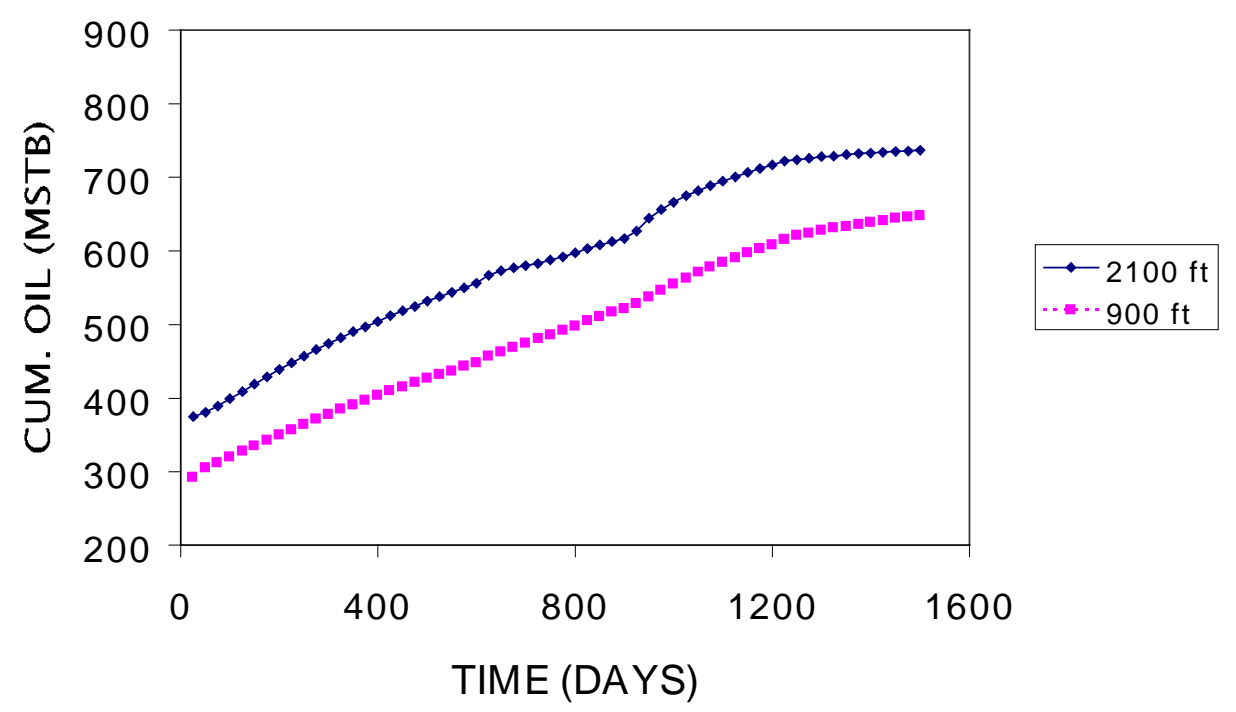

Fig. 5. Sensitivity of cumulative oil production to well length of the producer.

\section{CUMULATIVE OIL PRODUCTION}

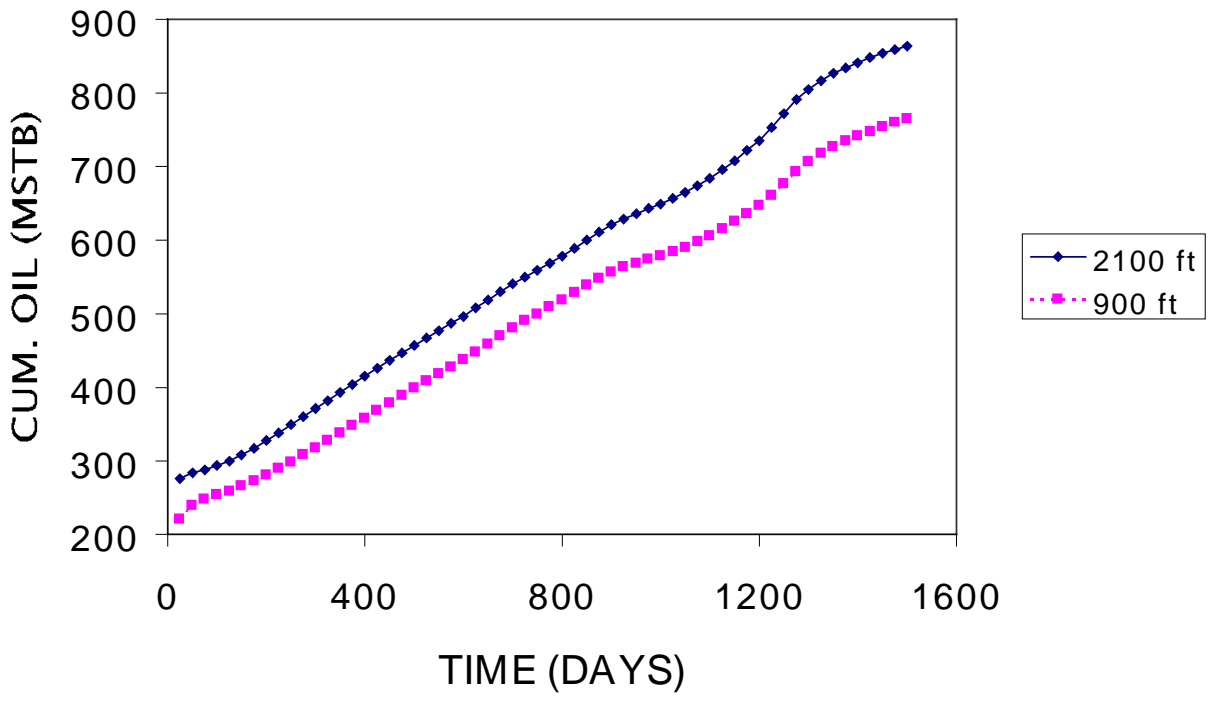

Fig. 6. Sensitivity of cumulative oil production to well length of the producer (with the second reservoir description). 
CUMULATIVE OIL PRODUCTION

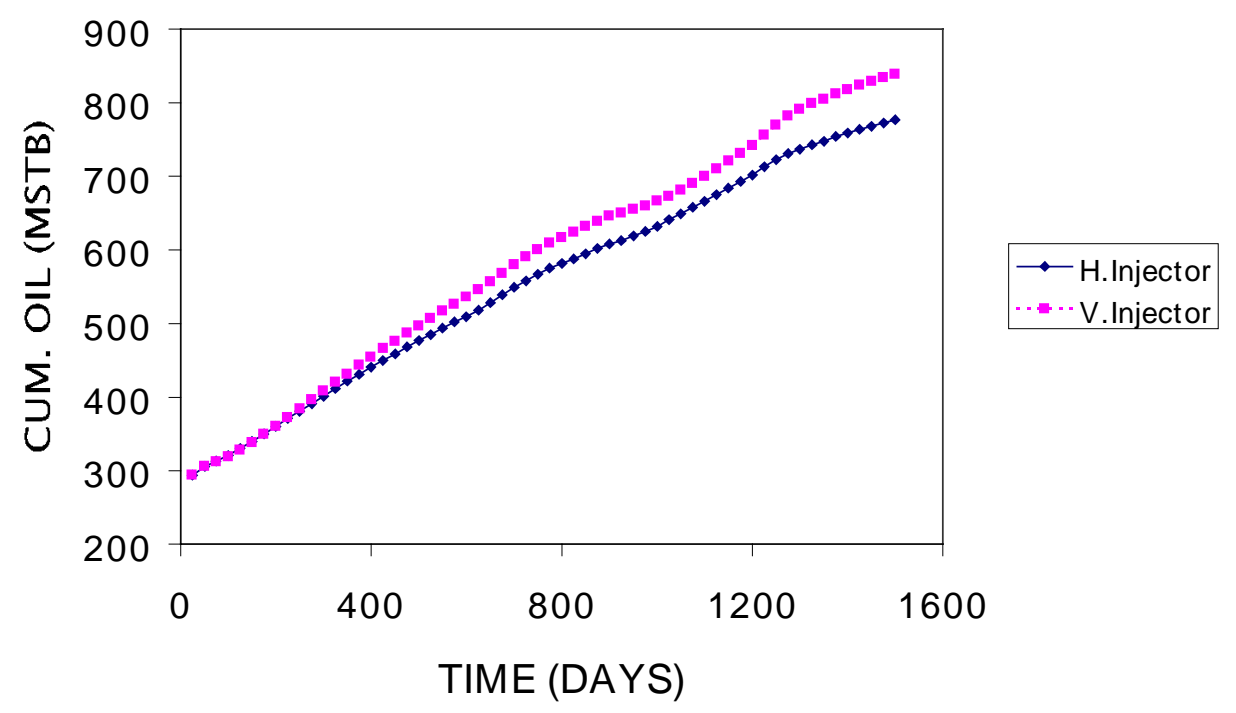

Fig. 7. Sensitivity of cumulative oil production to well type of the injector (with horizontal producer).

CUMULATIVE OIL PRODUCTION

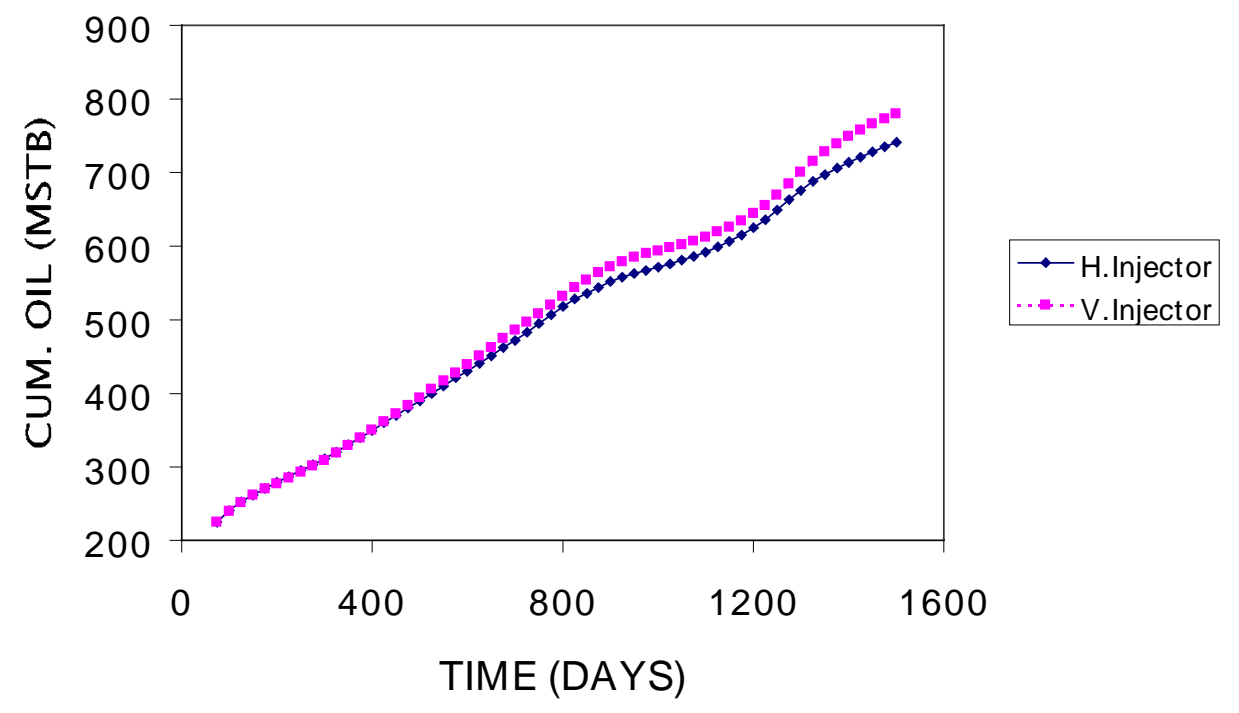

Fig. 8. Sensitivity of cumulative oil production to well type of the injector (with vertical producer). 
CUMULATIVE OIL PRODUCTION

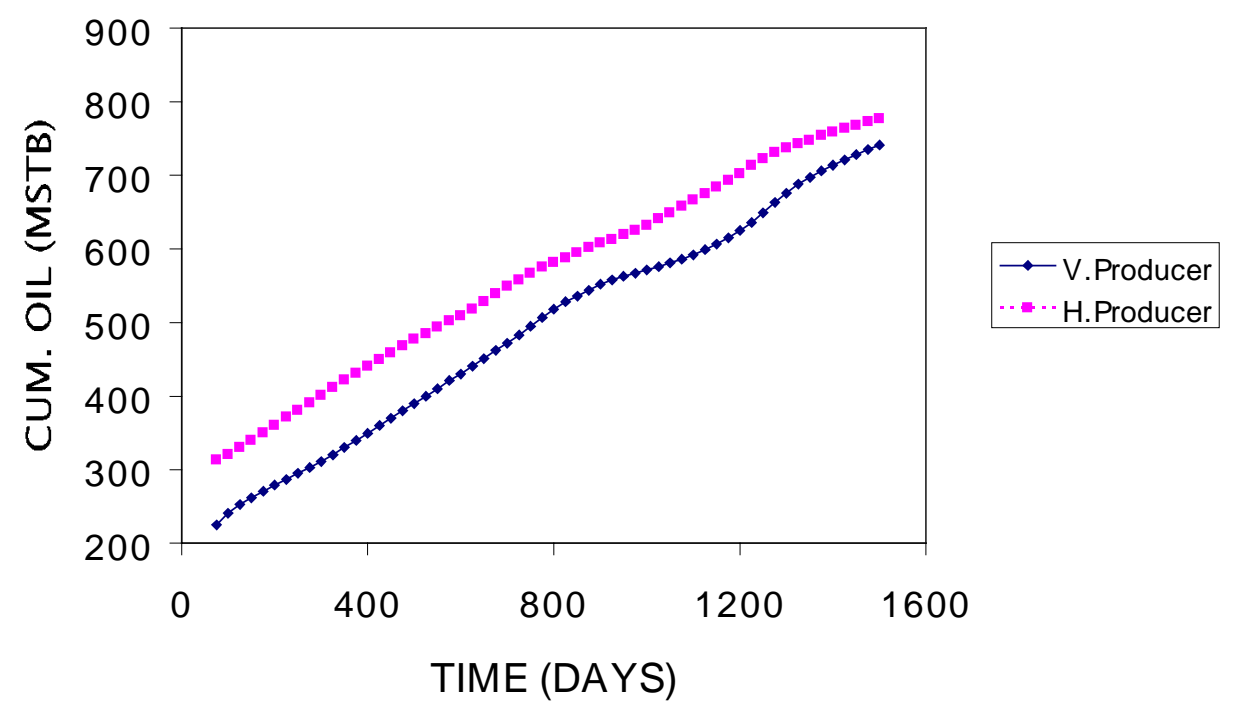

Fig. 9. Sensitivity of cumulative oil production to well type of the producer (with horizontal injector).

\section{CUMULATIVE OIL PRODUCTION}

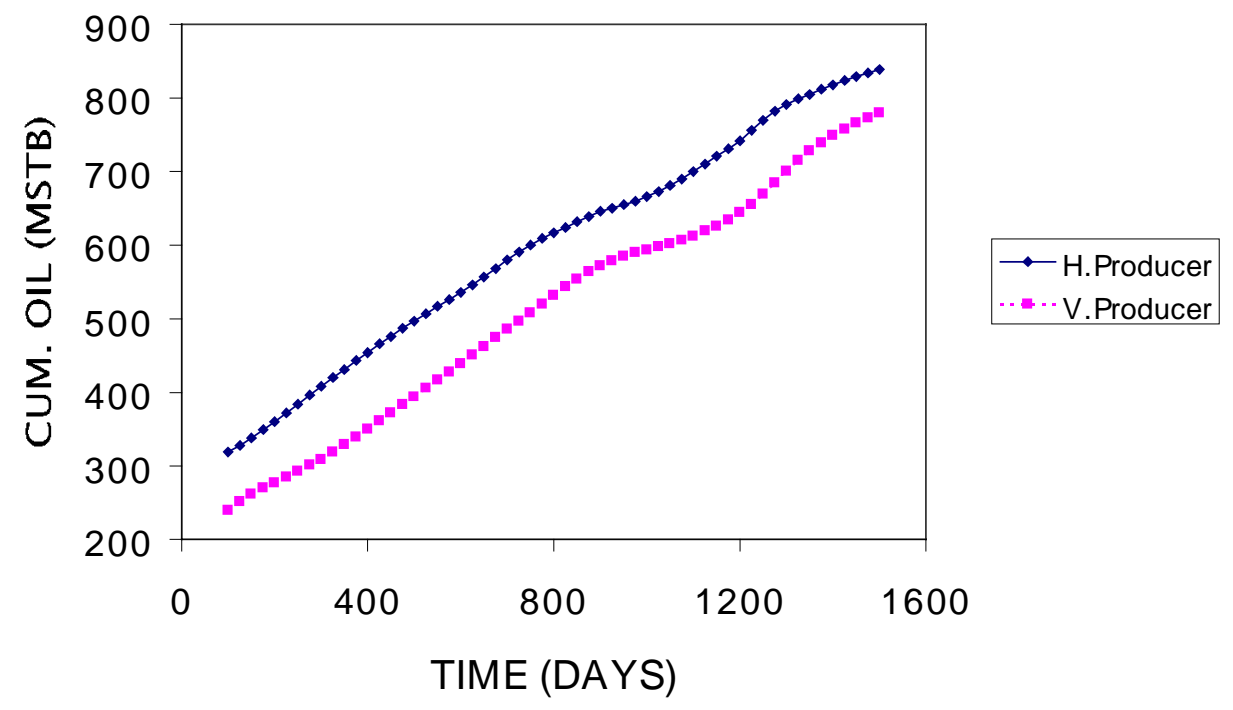

Fig. 10. Sensitivity of cumulative oil production to well type of the producer (with vertical injector). 